\title{
Socio-economic, Psychological and Situational Profile of Farmers Suicides in Aurangabad District, India
}

\author{
K.A. Kavar, J. M. Deshmukh and V.G. Dhulgand* \\ Department of Extension Education, College of Agriculture Latur, Vasantrao Naik \\ Marathwada Krishi Vidyapeeth Parbhani, (Maharashtra), India \\ *Corresponding author
}

\section{Keywords \\ Profile of suicide farmers, \\ Relationship of suicide farmer \\ Article Info \\ Accepted: \\ 10 April 2019 \\ Available Online: \\ 10 May 2019}

\section{A B S T R A C T}

The present investigation was conducted during year 2017-18 in Aurangabad district of Marathwada region in Maharashtra state. The main objective is to study the personal, socio-economic, psychological and situational characteristics of the farmer's families who committed suicides. From selected district five talukas were selected based on considerable farmer suicide cases. Thirty three villages were selected randomly based on considerable farmer suicide cases. Forty victims was selected proportionate method of random sampling for the study. It is noticed that most of the victims were having young age $(40.00 \%)$, education up to higher primary school level $(30.00 \%)$, victims belong to open category $(52.50 \%)$, victims were from joint family $(67.50 \%)$, medium family size $(70.00 \%)$, medium farming experience between 12 to 30 year $(70.00 \%)$, $(47.50 \%)$ victims were possessing small size of land holding i.e. (1.01 to 2.00 ha.), (60.00\%), Agriculture (only farming) as main occupation, medium annual income $(60.00 \%)$ i.e. Rs. 31383 to 111382, (60.00\%), medium socio-economic status, (45.00\%) medium type of land (soil), $(40.00 \%)$ no source of irrigation, $(85.00 \%)$ cotton based cropping system, $(95.00 \%)$ victims were founded indebted.

\section{Introduction}

Farmer suicide has turned out to be a major socio-economic concern in India that has resulted in profound implications on the quality life of farmers. According to the United Nations Commission on Sustainable Development (UNCSD), one farmer committed suicide for every 32 minutes between 1997 and 2005 in India. India's suicide rate of 11 per lakh people is roughly the global average. The highest rates are in Greenland (83 per lakh), Lithuania (38 per lakh) and South Korea (28.50 per lakh). China's rate (22.2 per lakh) is double India's. The Indian rate is lower than in rich countries with big welfare systems and very few farmers: Belgium (19), France (14.7), US (12.6), Japan (12.3), Germany (12.5) and the UK (11.8). Total of 3,19,026 have committed suicide in India since 1995 to 2016. Suicide incidence were reported from Maharashtra, Telangana, Andhra Pradesh, Panjab, kerala, Chhattisgarh, M.P. west Bengal and also other but Maharashtra is leading state according to NCRB report. The highest suicide cases was 
noted $(18,241)$ in year 2004, lowest suicide cases was noted $(8,295)$ in year 1995 . According to NCRB in Maharashtra state during last twenty one years period the incidences of suicide of farmers were increased tremendously. Since from January 1995 to December 2016 total 69,053 farmers committed suicide.

Farmers' suicide of Maharashtra, shows an increasing trend highest $(4,453)$ suicide cases were noted in year 2006, lowest $(1,083)$ suicide cases were as noted in year 1995. Farmer suicide in Marathwada region has gone exponentially in the last eight year. Total of 4,516 farmers committed suicide in Marathwada since 2010 to 2017. In the year 2018 (221) farmers committed suicide between 1 January to 25 March. The highest suicide cases were noted $(1,133)$ in year 2015 , lowest suicide cases noted (169) in year 2011. Maximum suicide incidence was reported from Beed district it contributes 27.30 percent out of total suicide in Marathwada (Source: ncrb.nic.in (2017).

\section{Materials and Methods}

The present investigation conducted in Aurangabad district in Marathwada region of Maharashtra state. From this district five talukas was selected based on considerable farmer suicide cases. Thirty three villages were selected randomly based on considerable farmer suicide cases. Forty victims was selected proportionate method of random sampling for the study. The ex-post facto research design was used for the study. The data was collected with help of pretested interview schedule from the victim's households as per their convenience at their home. The statistical methods and test such as frequency, percentage, mean, standard deviation and correlation of coefficient were used for analysis of data (Table 2).

\section{Results and Discussion}

So as to facilitate the comprehension of the sample and interpretation of results, a set of relevant personal, socio-economic and psychological characteristics of the respondents was included in the study. Therefore, the characteristics viz. Age, Education, Caste, Family size, Family type, Farming experience, Land holding, Subsidiary occupation, Annual income, Socio-economic status, Type of land, Irrigation facility, Productivity, Cropping pattern, Indebtedness, Livelihood pattern, Victims habits, Victims health, Family health and Family disputes were included in the study. The data on personal profile were sought, computed and discussed accordingly.

It was found from Table 1 that, nearly equal percentage of the victims was under young $(40.00 \%)$, followed by 37.50 per cent belonged to middle age and 22.50 per cent belonged to old age category. As regard to education revealed that, 30.00 per cent victims were having education up to higher primary school level education, 20.00 per cent victims were having education up to primary school, 17.50 per cent victims were up to higher secondary level and 15.00 per cent were observed in middle school, technical education level and illiterate level equal 7.50 per cent, very few $(2.50 \%)$ were from graduate level education and none of them from the post graduate. As regard to category revealed that, majority $(52.50 \%)$ suicide cases were belonged to open category, followed by Nomadic Tribe (NT-B) category 12.50 per cent, Nomadic Tribe (NT-C) 12.50 per cent, Nomadic Tribe (NT-D) 7.50 per cent, Other Backward Class (OBC) 5.00 per cent, 5.00 per cent victim's were observed from Special Backward Class (SBC), 5.00 per cent Schedule Caste (SC) and no one was found from ST category. It was observed that maximum $(67.50 \%)$ victims were from joint 
type of families and 32.50 per cent victims belong to nuclear type of family.

It was observed that, majority $(70.00 \%)$ suicide case was belonging to medium family size having 4 to 7 family members. While, 20.00 per cent victims were from big family size (above 8 members) and 10.00 per cent victims having small family size (up to 3 members). As regard to farming experience revealed that, majority $(70.00 \%)$ victims had farming experience between 12 to 30 years, followed by 17.50 per cent victims had farming experience up to 11 years and 12.50 per cent victims had farming experience above 31 years. 47.50 per cent of the victim's were small size of land holding i.e. 1.01 to 2.00 ha, followed by 32.50 per cent victims were semi-medium size of land holding i.e. 2.01 to 4.00 ha, 12.50 per cent victims were marginal farmers possessing land up to 1.00 ha, 7.50 per cent victims had medium size of land holding i.e. 4.01 to 10.00 ha.

As regard to subsidiary occupation revealed that, less than half 42.50 per cent of victims were possessed agriculture (only farming) as main occupation, 32.50 per cent of victims was engaged in farm labour, 10.00 per cent deceased farmers were doing agriculture and other occupation such as non-professional business with farming, 5.00 per cent victims were possessed dairy as an allied occupation through buffalo rearing in addition to farming and monthly income from salary/pension was noted in 5.00 per cent victims. 60.00 per cent of the victims had medium annual income i.e. Rs. 31,383 to $1,11,383$, followed by 37.50 per cent of victim belonged from high income group with annual income up above Rs. $1,11,383$ and 2.50 per cent of victims had low annual income up to Rs.31,382. As regard to socio-economic status revealed that, more than half $(60.00 \%)$ of the victims were categorized in medium level of socio- economic status, followed by 22.50 per cent victims were in low level of socio-economic status and 17.50 per cent victims high level of socio-economic status.

It was revealed that, less than half $(45.00 \%)$ respondents having medium type of land (soil) followed by 35.00 per cent were having heavy soil type of land and 20.00 per cent respondent having light soil type of land. 40.00 per cent deceased farmers not having any source access the irrigation source, followed by 35.00 per cent victims having well/tube well source to access the irrigation, 17.50 per cent canal, 5.00 per cent victims are farm pond source irrigation and 2.50 per cent victims had river as irrigation source. As regard to crop productivity revealed that, average productivity of all crops during 20152016 was very low, it might be due to the drought year. Cotton, 19.5qts/ha, soybean 13.17qts/ha, jowar 15.32 qts/ha, tur 12.45 qts/ha, gram 14.27 qts/ha, wheat 16.75 qts/ha.

As regard to cropping pattern revealed that, majority of victims were growing cotton 85.00 per cent, followed by soybean 70.00 per cent, red gram 60.00 per cent, sorghum 30.00 per cent and other 20.00 per cent in kharif season. In rabbi season, majority of victims were found growing gram 45.00 per cent, followed by sorghum 27.00 per cent, wheat 15.00 per cent and other 22.50 per cent in rabbi season. It was observed that, more than half $(57.50 \%)$ victims had taken monocropping and 42.50 per cent victims had taken intercropping in cropping system. As regard to indebtedness position of the victims revealed that, out of 40 victims 38 victims were found indebted, that mean majority $(95.00 \%)$ victims have an obligation to pay debts to borrowed agencies/ sources, where as only 2 victims 5.00 per cent were not found indebted. 
Table.1 Distribution of victims according to their personal, socio-economical, psychological and situational characteristics $(\mathrm{N}=40)$

\begin{tabular}{|c|c|c|c|}
\hline Sl. No. & Category & Frequency $(\mathbf{F})$ & Per cent $(\%)$ \\
\hline 1) & \multicolumn{3}{|l|}{ Age (Years) } \\
\hline 1. & Young (Up to 35 ) & 16 & 40.00 \\
\hline 2. & Middle (36 to 50) & 15 & 37.50 \\
\hline 3. & Old (50 and Above) & 09 & 22.50 \\
\hline 2) & \multicolumn{3}{|l|}{ Education } \\
\hline 1. & Illiterate & 03 & 07.50 \\
\hline 2. & Primary school & 08 & 20.00 \\
\hline 3. & Higher Primary & 12 & 30.00 \\
\hline 4. & Middle school & 06 & 15.00 \\
\hline 5. & Higher Secondary & 07 & 17.50 \\
\hline 6. & Graduate & 01 & 02.50 \\
\hline 7. & Post Graduate & 00 & 00.00 \\
\hline 8. & Technical education & 03 & 07.50 \\
\hline 3) & \multicolumn{3}{|l|}{ Caste } \\
\hline 1. & Schedule Caste (SC) & 02 & 05.00 \\
\hline 2. & Schedule Tribe (ST) & 00 & 00.00 \\
\hline 3. & Vimukta Jati $\quad$ (VJ -A) & 00 & 00.00 \\
\hline 4. & Nomadic Tribe (NT-B) & 05 & 12.50 \\
\hline 5. & Nomadic Tribe (NT-C) & 05 & 12.50 \\
\hline 6. & Nomadic Tribe (NT- D) & 03 & 07.50 \\
\hline 7. & Other Backward Class (OBC) & 02 & 05.00 \\
\hline 8. & Special Backward Class (SBC) & 02 & 05.00 \\
\hline 9. & Open & 21 & 52.50 \\
\hline 4) & \multicolumn{3}{|l|}{ Family type } \\
\hline 1. & Nuclear & 13 & 32.50 \\
\hline 2. & Joint & 27 & 67.50 \\
\hline 5) & \multicolumn{3}{|l|}{ Family Size } \\
\hline 1. & Small (up to 3) & 04 & 10.00 \\
\hline 2. & Medium (4 to 7 ) & 28 & 70.00 \\
\hline 3. & High (Above 8) & 08 & 20.00 \\
\hline 6) & \multicolumn{3}{|l|}{ Farming experience } \\
\hline 1. & Low (up to 11 yrs) & 07 & 17.50 \\
\hline 2. & Medium (12 to 30$)$ & 28 & 70.00 \\
\hline 3. & High (Above 31 yrs.) & 05 & 12.50 \\
\hline 7) & \multicolumn{3}{|l|}{ Land holding } \\
\hline 1. & Marginal (Up to 1.00 ha.) & 05 & 12.50 \\
\hline 2. & Small (1.01 to 2.00 ha.) & 19 & 47.50 \\
\hline 3. & Semi-medium (2.01 to 4.00 ha.) & 13 & 32.50 \\
\hline 4. & Medium (4.01 to 10.00 ha.) & 03 & 07.50 \\
\hline 8) & \multicolumn{3}{|l|}{ Subsidiary occupation } \\
\hline
\end{tabular}




\begin{tabular}{|c|c|c|c|}
\hline 1. & Agriculture (only farming) & 17 & 42.50 \\
\hline 2. & Agriculture + Labour & 13 & 32.50 \\
\hline 3. & Agriculture + Allied occupation & 00 & 0.00 \\
\hline i. & Agriculture + Dairy ( Buffalo) & 02 & 05.00 \\
\hline ii. & Agriculture + Goat, Sheep farming & 01 & 02.50 \\
\hline iii. & Agriculture + Poultry, Duck farming & 01 & 02.50 \\
\hline iv. & Agriculture + Sericulture farming & 00 & 00.00 \\
\hline 4. & Agriculture + Other occupation & 04 & 10.00 \\
\hline 9) & \multicolumn{3}{|l|}{ Annual income } \\
\hline 1. & Low (up to 31382) & 01 & 02.50 \\
\hline 2. & Medium (31383 to 111382$)$ & 24 & 60.00 \\
\hline 3. & High (Above 111383) & 15 & 37.50 \\
\hline 10) & \multicolumn{3}{|l|}{ Socio-economic status } \\
\hline 1. & Low (up to 8) & 09 & 22.50 \\
\hline 2. & Medium (9 to14) & 24 & 60.00 \\
\hline 3. & High (Above 14) & 07 & 17.50 \\
\hline 11) & \multicolumn{3}{|l|}{ Type of land } \\
\hline 1. & Light soil & 08 & 20.00 \\
\hline 2. & Medium soil & 18 & 45.00 \\
\hline 3. & Heavy soil & 14 & 35.00 \\
\hline 12) & \multicolumn{3}{|l|}{ Irrigation facilities } \\
\hline 1. & No source & 16 & 40.00 \\
\hline 2. & Canal & 07 & 17.50 \\
\hline 3. & Well / Tube well & 14 & 35.00 \\
\hline 4. & River & 01 & 02.50 \\
\hline 5. & Farm pond & 02 & 05.50 \\
\hline 13) & Crops & Aver: & (qts./ ha.) \\
\hline 1. & Cotton & & \\
\hline 2. & Soyabean & & \\
\hline 3. & Sorghum & & \\
\hline 4. & Tur & & \\
\hline 5. & Gram & & \\
\hline 6. & Wheat & & \\
\hline \multirow[t]{2}{*}{ 14) } & \multicolumn{3}{|l|}{ Cropping pattern (last three years) } \\
\hline & \multicolumn{3}{|l|}{ A) Kharif } \\
\hline 1. & Cotton & 34 & 85.00 \\
\hline 2. & Soyabean & 28 & 70.00 \\
\hline 3. & Sorghum & 12 & 30.00 \\
\hline 4. & Tur & 24 & 60.00 \\
\hline \multirow[t]{2}{*}{5.} & Other & 08 & 20.00 \\
\hline & \multicolumn{3}{|l|}{ B) Rabbi } \\
\hline 1. & Wheat & 11 & 27.50 \\
\hline 2. & Gram & 18 & 45.00 \\
\hline 3. & Jowar & 13 & 32.50 \\
\hline
\end{tabular}




\begin{tabular}{|c|c|c|c|c|}
\hline 4. & Other & 09 & \multicolumn{2}{|r|}{22.50} \\
\hline 15) & \multicolumn{4}{|l|}{ Type of cropping system } \\
\hline 1. & Monocropping & 23 & \multicolumn{2}{|r|}{$\mathbf{5 7 . 5 0}$} \\
\hline 2. & Intercropping & 17 & \multicolumn{2}{|r|}{42.50} \\
\hline 16) & Indebtedness position of the victims & & & \\
\hline 1. & Indebted victims & 38 & \multicolumn{2}{|r|}{95.00} \\
\hline 2. & Free from debts & 02 & \multicolumn{2}{|r|}{05.00} \\
\hline 17) & \multicolumn{4}{|l|}{ Livelihood pattern } \\
\hline 1. & Agriculture & 39 & 97.50 & 4412456 \\
\hline 2. & Allied occupation A Allied occupation & 10 & 25.00 & 286720 \\
\hline 3. & Wages earning & 13 & 32.50 & 275800 \\
\hline 4. & Non profession business & 09 & 22.50 & 525380 \\
\hline 5. & Service/pension & 02 & 05.00 & 80000 \\
\hline 6. & Total income (A) & 40 & 00.00 & 5380356 \\
\hline 7. & Expense incurred on food & 40 & 100.00 & 423500 \\
\hline 8. & Total non food & 40 & 100.00 & 645320 \\
\hline 9. & Total expenditure (B) & 40 & 00.00 & 1068820 \\
\hline 10. & Surplus/deficit (+/-) (A-B) & 40 & 00.00 & 4311536 \\
\hline 18) & \multicolumn{4}{|l|}{ Victim's habits } \\
\hline 1. & Chewing of tobacco & 15 & \multicolumn{2}{|r|}{$\mathbf{3 7 . 5 0}$} \\
\hline 2. & Alcoholism & 07 & \multicolumn{2}{|r|}{17.50} \\
\hline 3. & Smoking (Cigar) & 04 & \multicolumn{2}{|r|}{10.00} \\
\hline 4. & Smoking (bidi) & 06 & \multicolumn{2}{|r|}{15.00} \\
\hline 5. & Ganja & 03 & \multicolumn{2}{|r|}{07.50} \\
\hline 6. & No habbits & 05 & \multicolumn{2}{|r|}{12.50} \\
\hline 19) & \multicolumn{4}{|l|}{ Victim's health } \\
\hline 1. & Diabetic & 02 & \multicolumn{2}{|r|}{05.00} \\
\hline 2. & Tuberculosis(T.B.) & 01 & \multicolumn{2}{|r|}{02.50} \\
\hline 3. & Breaking the hand & 01 & \multicolumn{2}{|r|}{02.50} \\
\hline 4. & Breaking the leg & 01 & \multicolumn{2}{|r|}{02.50} \\
\hline 5. & Cancer & 02 & \multicolumn{2}{|r|}{05.00} \\
\hline 6. & Brain Tumor & 01 & \multicolumn{2}{|r|}{02.50} \\
\hline 7. & Cramp & 01 & \multicolumn{2}{|r|}{02.50} \\
\hline 20) & \multicolumn{4}{|l|}{ Victims Family health problem } \\
\hline 1. & Family members having health problem & 28 & \multicolumn{2}{|r|}{$\mathbf{7 7 . 5 0}$} \\
\hline 2. & $\begin{array}{l}\text { Family members were free from health } \\
\text { problem }\end{array}$ & 12 & \multicolumn{2}{|c|}{22.501} \\
\hline 21) & Family disputes & Frequency & $\%$ & Reasons \\
\hline 1 & With his wife & 06 & 31.57 & Domestic \\
\hline 2 & With his brother & 05 & 26.31 & Domestic \\
\hline 3 & Victims and his son & 04 & 21.50 & Domestic \\
\hline 4 & Victims and neighbour & 03 & 15.78 & Farm related \\
\hline 5 & Victims and relative & 01 & 05.26 & Domestic \\
\hline
\end{tabular}


Table. 2 Coefficient of Correlation of selected characteristics of the victims with their identified number of Socio-psycho risk factors of suicides $(\mathrm{N}=40)$

\begin{tabular}{|c|c|c|}
\hline Sr. No. & Characteristics & "r"value \\
\hline \multicolumn{3}{|c|}{ A) Personal } \\
\hline 1 & Age & $0.540 * *$ \\
\hline 2 & Education & $0.058^{\mathrm{NS}}$ \\
\hline 3 & Caste & $0.086^{\mathrm{NS}}$ \\
\hline 4 & Family size & $0.144^{\mathrm{NS}}$ \\
\hline 5 & Family type & $-0.187^{\mathrm{NS}}$ \\
\hline 6 & Farming experience & $0.477 * *$ \\
\hline \multicolumn{3}{|c|}{ B) Socio-economic } \\
\hline 7 & Land holding & $0.212 *$ \\
\hline 8 & Subsidiary occupation & $0.206^{*}$ \\
\hline 9 & Annual income & $0.257 * *$ \\
\hline 10 & Socio-economic status & $0.246^{*}$ \\
\hline \multicolumn{3}{|c|}{ C) Situational } \\
\hline 11 & Type of land & $-0.209 *$ \\
\hline 12 & Irrigation facilities & $0.198 *$ \\
\hline 13 & Agriculture infrastructure & $0.453 * *$ \\
\hline 14 & Productivity & $0.227 *$ \\
\hline 15 & Cropping pattern & $0.206^{*}$ \\
\hline 16 & Indebtedness & $0.315 * *$ \\
\hline 17 & Livelihood pattern & $-0.285 * *$ \\
\hline 18 & Extent of family responsibility fulfilled & $0.589 * *$ \\
\hline \multicolumn{3}{|c|}{ D) Socio-psychological } \\
\hline 18 & Victims habits & $0.305 * *$ \\
\hline 19 & Victim's health & $0.290 * *$ \\
\hline 20 & Family health & $0.406 * *$ \\
\hline 21 & Family disputes & $0.431 * *$ \\
\hline 22 & Victims habits & $0.305 * *$ \\
\hline
\end{tabular}

** Significant at 0.01 level of probability *Significant at 0.05 level of probability

It was also observed during study that, 97.50 per cent victims and his family had got the average total income Rs.44,12,456 from agriculture, followed by 32.50 per cent victims and his family had got the average total income Rs. 2,75,800 from wages, 25.00 per cent victims and his family had got the total average income Rs. 2,86,720 from allied occupation such dairy, goat farming, respectively 22.50 per cent victims and his family had got the average total income Rs.5,25,380 from any professional and non professional business and while remaining 5.00 per cent victims and his family had got the average total income Rs. 80,000 from service/pension. In case of expenditure overall 100.00 per cent victims had the average expenditure of Rs.6,45,320 on food, Followed by 100.00 per cent victims had the average expenditure of Rs.10,68,820 on non food items. As regard to victim's habits revealed that, less than half $(37.50 \%)$ of the deceased farmers possessed regular tobaccochewing habit, followed by 17.50 per cent 
having regular alcohol drinking habit. While 10.00 per cent and 15.00 per cent victims were observed under smoking cigar and bidi, habits. Majority $(87.50 \%)$ deceased farmers were possessed either one or more bad habits with them, like chewing of tobacco, bidi, smoking, alcohol addiction or gambling. Whereas 12.50 per cent per cent were free from bad habits. As regard to victim's health revealed that, 5.00 per cent victims had cancer and 5.00 per cent had diabetic followed by 2.50 per cent victims did operation of tuberculosis, 2.50 per cent did operation of breaking of hand, 2.50 per cent had breaking the leg, 2.50 per cent had cramp and brain tumor. As regard to victim's family health problem that, majority $(77.50 \%)$ was free from health problems, and remaining 22.50 per cent victims having health problem. 31.57 per cent dispute/ quarrel were noticed with his spouse due to domestic reasons, followed by quarrel with brother in $(26.31 \%)$ victims due to domestic reasons and 21.50 per cent victims were noticed his son dispute due to domestic reasons only.

The result presented that, out of 22 variables, Livelihood pattern show negative and highly significant relationship, type of land show negative and significant relationship and Family type show negative non-significant of the socio-psycho risk factor of suicide at 0.01 level of probability. Other 19 variables namely Age, Farming experience, Land holding, Subsidiary occupation, Annual income, Socio-economic status, Irrigation facilities, Agriculture infrastructure, Productivity, Cropping pattern, Indebtedness, Extend of family responsibility fulfilled, Victims habits, Victims health, Victims family health and Family dispute show positive and highly significant relationship with the socio-psycho risk factors of farmers suicide and Education and Caste was show non-significant relationship with the sociopsycho risk factors of farmers suicide.
The conclusion is as follows:

It was found from present study observed that majority of victims were under young age, higher primary educational level, open category of caste, joint type of family, medium size of family and medium level of farming experience, small size of land holding, subsidiary occupation maximum victims were agriculture (only farming), medium level of annual income, medium level of socio-economic status, medium type of land (soil), cotton and soybean based cropping pattern, no any source of irrigation facilities, maximum deceased farmers one or more bad habits.

The result showed that, Livelihood pattern show negative and highly significant relationship, type of land show negative and significant relationship, Family type show negative non-significant relationship with socio-psycho risk factor of suicide. Other 19 variables namely Age, Farming experience, Land holding, Subsidiary occupation, Annual income, Socio-economic status, Irrigation facilities, Agriculture infrastructure, Productivity, Cropping pattern, Indebtedness, Extend of family responsibility fulfilled, Victims habits, Victims health, Victims family health and Family dispute show positive and highly significant relationship with the socio-psycho risk factors of farmers suicide and Education and Caste was show non-significant relationship with the sociopsycho risk factors of farmers suicide.

\section{References}

Amma, (2007). Farmer relief Champaign on International farmer suicide crisis UNCSD.

Behere, P.B., and Behere, A.P. (2008). Farmer suicides in Vidarbha region of Maharashtra State: A myth or reality Indian Journal of Psychiatry.50 pp: 
124-127

Choudhary P.R., Padhi, T.K. Arman, Mohanty and Somal A.K. (2016) Why Farmer Quite A Study on Farmer Suicide in Odisha. Indo-Global Social Service Society.

Kale, N.M., 2008, Socio-economic, psychological and situational causes of farmer suicide of farmer in Vidharbha region Ph.D. Thesis Dr.
PDKV Akola.

Macharia, I., 2015. Determinants of Farmers' Suicides in Andhra Pradesh: An Analysis. International Journal of Academic Research. 2(1) pp: 81-87.

Merriott Domonic, 2017. Factors Associated with the Farmer Suicide Crisis in India. Journal of Epidemiology and Global Health, 6 pp: 217-227.

\section{How to cite this article:}

Kavar, K.A., J. M. Deshmukh and Dhulgand, V.G. 2019. Socio-economic, Psychological and Situational Profile of Farmers Suicides in Aurangabad District. Int.J.Curr.Microbiol.App.Sci. 8(05): 892-900. doi: https://doi.org/10.20546/ijcmas.2019.805.104 